\title{
Fra en kniplerskes ugebog
}

\author{
Af Ebbi Busch.
}

I flere af landets arkiver findes et omfattende materiale, der på forskellig vis belyser Tønderkniplings-industrien. Det er derimod sjældnere at finde arkivalier, som beretter om en enkelt kniplerskes liv og arbejdsmetode. Fra de mere end 200 år, industrien bestod, haves så godt som kun de skønne kniplinger som tavse vidnesbyrd om tusindvis af flittige hænders arbejde. Om den store skare af anonyme kvinder, kniplerskerne, vides der kun lidt. Ved et rent tilfælde er det imidlertid lykkedes at kunne belyse et par arbejdsår hos en professionel kniplerske.

Haderslev Amts Museum besidder et knipleskrin af den sædvanlige tønderske form (fig. 1) bestående af et træskrin med skråpude, stoppet med enghø og beklædt med blårlærred, der langs kanterne holdes fast af en læderstrimmel med messingsøm. ${ }^{1}$ Skrinet er malet mørkegrønt med buer af hvidt, kantet med rødt, ligesom alle kanter og lister er rødmalet. På klappen på skrinets bagside findes årstallet 1:7:9:1 under initialerne K:P:A:D. Midt på skrinet er et pergaments prikbrev fastnaglet under en hærskare af spinkle, små messingknappenåle, der var i færd med at forme en påbegyndt knipling, hvis tråde er beskyttet mod slid fra prikbrevets nubrede overflade af en smal trådbeskytter, tildannet af en vidje. På hver side af prikbrevet er forankret to rektangulære "sidebreve af læder med huller til indstikning af stilsene, de lange nåle, der holder de ledige kniplestokke $i$ ave. To sådanne stilse af messing med trekløverformet hoved findes som tilbehør til skrinet. \Skræwlet «, det rektangulære læderstykke, der beskytter skrinets betræk mod slid fra de livligt dansende kniplestokke under arbejdet, er her dekoreret langs kanten med et lille indstemplet motiv $\mathrm{i}$ form af et bølget bånd med små stjerner og større rosetter. Den gængse nålepude er erstattet af lapper af forskelligt farvet 


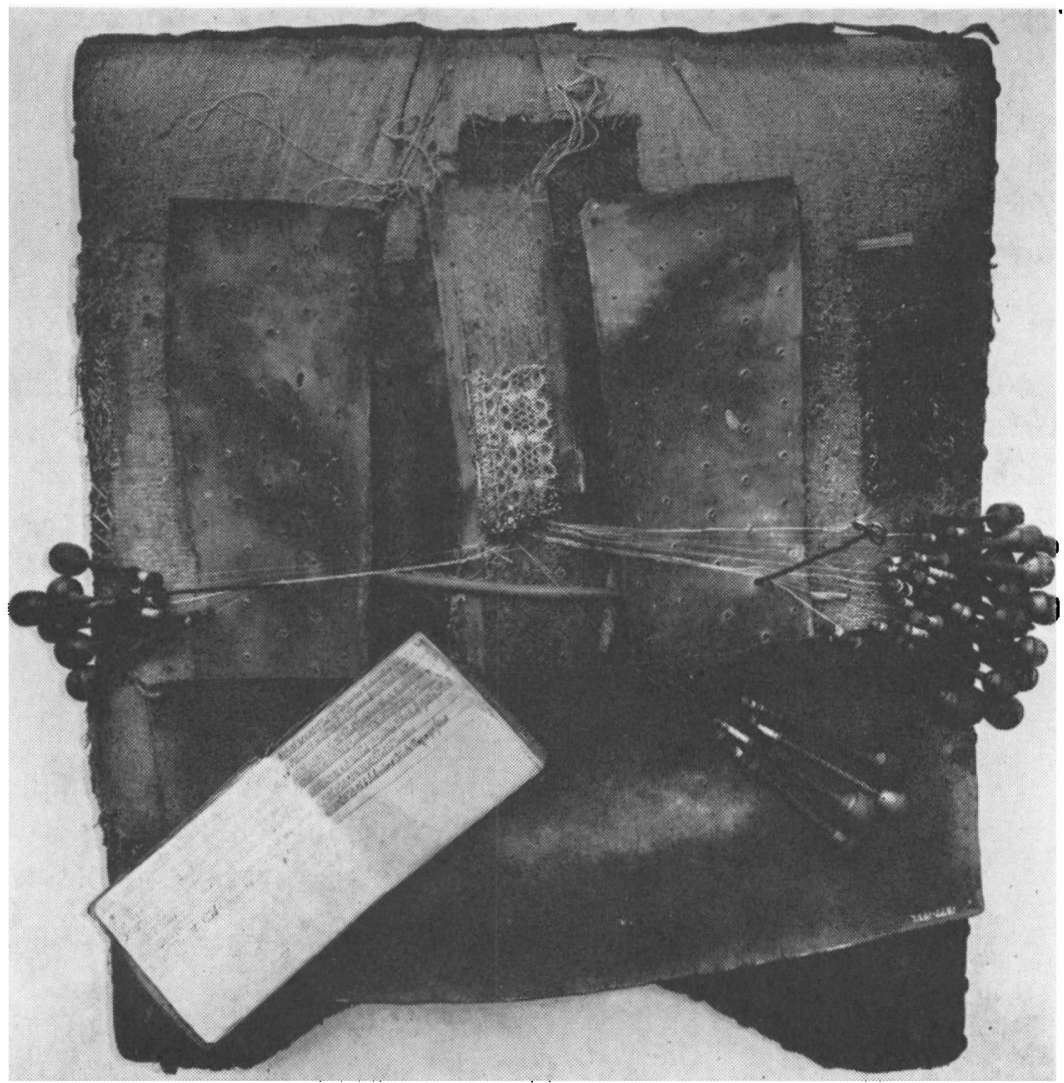

Fig. I. Knipleskrin fra Gotterup med opslagen ugebog.

tøj, som blev udskiftet, nâr de blev for lasede. Foroven tilhøjre på skråpuden er indstukket, tæet ved sidebrevet, et lille redskab, bestående af en näl med skaft af groft forarbejdet træ. På grund af sin lidenhed har den været uegnet som priksyl til fremstilling af prikbreve. Sådanne redskaber, der af og til findes i skufferne på knipleskrinene, har uden tvivl været brugt til udredning af spegede tråde, noget der let fandt sted, især efter en "opflytning " Kun en del af det oprindelige antal kniplestokke er bevaret. De lå $i$ en af de to skuffer, som findes på skrinets langsider. Nogle af disse stokke er af drejet træ og afviger $i$ form fra den alminde- 
lig kendte tonderske ved at have en ægformet dop, en type, der er meget udbredt inden for kniplingscentrene i Flandern, og som også er fundet på plads pá knipleskrin fra Tonderegnen, opsat med kniplinger fra slutningen af 1700 tallet. ${ }^{2}$ Da det her omhandlede skrin fra Haderslev Museum kan dateres til 1791, er det meget muligt, at stokke af denne form kan tilskrives samme dato.

Nogen skønhedsåbenbaring er dette skrin ikke, betrækket er laset og meget fedtet, især over den indbugning, som vendte ind mod kniplersken, når hun arbejdede. Stopningen af enghø stikker ud her og der, knap mangler pâ skuffe og klap, alt tyder pă, at det er et gammelt skrin, der er blevet brugt længe og ihærdigt af' en yderst sparsommelig person, som kviede sig ved at of re et nyt betræk endsige at anskalfe sig en rigtig nálepude. Intet af tilbehøret er der kælet for, hverken stokke eller stilse har de små perleprydelser, som ofte træffes på 1800 tallets knipletilbehør.

Også prikbrevet, det mønster efter hvilket kniplingen tager form ved hjælp af indstikning af knappenalene, er uhyre slidt. En afprikning af mønstret på papir viste da også, at det var nodvendigt at "rette mønstret op", dersom man nu skulle kunne kniple en velformet knipling derefter. Metervis al den samme knipling må være vokset frem under de ideligt flyltede knappenale, hvorved nálehullerne stedse forgrovedes, og en udpræget skævhed i mønstret opstod, som kun en meget habil kniplerske kunne vide at fai af værget.

Kniplingen, hvoraf der nu kun er en stump tilbage (se fig. 1) har følgende karakter: den er $0,035 \mathrm{~m}$ bred med bred, tvedelt tunge med "omkast (picols) og har en rapport (d. v. s. det monster der gentages) på $0,019 \mathrm{~m}$. Til fremstillingen af denne knipling har der været anvendt 27 par stokke og 7 storstokke til konturtrảden eller følgetråden, der forlenede mønstrel med dybdevirkning. Bunden er tyll, og motivet er meget enkelt, nærmest geometriseret, bestảende af en række tætstillede cirkler opbygget af 4 huller og 2 lærredspletter om centrum af rosenbund. Derover findes i kanten modsat tungen 1 hulrække med små trefligede vifter. Kniplingen tilhorer den gruppe, der betegnes Lille kniplinger efter det store kniplingscentrum i Nordfrankrig. Disse typer tilhører 1800 tallet, og den stærkt geometriserede form er den sidste udluber af denne kniplingstype. En knipling magen til den på skrinet 
findes bl. a. på et lin fra Nordsjælland. ${ }^{3}$ En varieret form, med en lille lærredsplet på cirklens rosenbund, er mere udbredt her i landet og forekommer på en halv snes hovedtøjsdele, hovedsagelig fra Lolland-Falster og Møn. Begge varianter figurerer ydermere $\mathrm{i}$ en kniplingshandlers mønsterprøvebog fra 1885 , der har tilhørt kniplingshandler Hans Hansen, Ballum. ${ }^{4}$

Da prikbrevet har 11 rapporter, har det ved starten været muligt for kniplersken at kniple 11 takker (tunger), for hun skulle "flytte op" (omsætte), et noget omstændeligt arbejde, som krævede indpakning af hele raden af stokke for at forhindre en eventuel infiltring af de fine tråde, dernæst en forsigtig udtagning af alle nålene, således at knipling og stokke kunne løftes op, hvorved den på prikbrevet nederst kniplede tunge kom til at dække den øverste, i hvilken nålene atter fæstnedes, så der nu kunne fortsættes, indtil en ny opflytning måtte foretages efter 10 rapporter.

Knipleskrinet indlemmedes i Haderslev Amts Museum i tiden mellem 1898 og 1905 og opgives at stamme fra en gammel kone $i$ Gøtterup, Tislund sogn, Haderslev amt. Ifølge skik og brug på knipleegnen gik et skrin ofte i arv fra generation til generation, og i tidens løb blev det undertiden pudset op i form af overmaling, således at den første ejers initialer gik tabt. Det er således sjældent at finde et skrin med initialer og årstal fra 1700 tallet og en stor sjældenhed at kunne få sâ gode oplysninger, som findes om dette skrin fra Haderslev Museum.

I en af de små sideskuffer lå nedkrammet en lille uanseelig bog, der ved første øjekast ikke bød på synderligt af interesse, gennemsyret som den var af fedtstof, der gjorde det umuligt at læse, hvad der stod prentet på de små sider med gnidret, gotisk skrift, men holdt op mod lyset fangede enkelte ord som »Tak " og "Alen « øjet, og det var nok til, at den blev indsendt til konservering på Nationalmuseet, hvor et hurtigt skønhedsbad i petroleumsæther bragte bogen tilbage til sin oprindelige skikkelse.

Det er et lille hjemmelavet hæfte, der måler $0,09 \mathrm{~m} \times 0,11 \mathrm{~m}$, med omslag af karduspapir. Siderne er linieret med blyant med 10-13 linier, som oftest lidt på sned, og det er pudsigt at se, at fingeren engang imellem er kommet i vejen for linealen, så linien slår en bugt. På nogle af de første sider har kniplersken allernederst på den højre halvside prentet sit fulde navn og datoen for 
den sidst indførte optælling af takkerne. Som det tit sker for gamle folk, er hun løbet lidt sur $i$ årets måneder, idet hun på side 3 skrev 4. april i stedet for 4 . maj, som det skulle have været.

På titelbladet står prentet med blæk (uden indstregede linier): "Denne bog tilhører Berthe Marie Alexandersen 1894. Nu er der sidst indskreven i $\mathfrak{x}$ ug Bog 1228 A1 17 Tak 29. September 19. Sønda $[g]$ efter Trinitatis".

Før bogen udleverer sin hemmelighed, var det passende at præsentere bemeldte Berthe Marie Alexandersen. Dette gores ved et kik i kirkebogen for Tislund kirke, ${ }^{5}$ hvorved det erfares, at hun døde den 27. juli 1899 , blev begravet den 31 . samme måned efter ligtale $\mathrm{i}$ kirken og velsignelse ved graven. Det kan endvidere oplyses, ${ }^{6}$ at hun blev født i Østerlinnet den 18. februar 1819 og døbt dagen efter, at hun var datter af gårdmand Nis Sorensen og hustru Anna Catrine Andersdaller. Familien flyttede omkring nytår 1829-30 til Gotterup, ${ }^{7}$ hvor Berthe Marie Sorensen blev konfirmeret $i$ 1835, efter at have fået den fornødne kundskab i de befalede lærebøger og med stempel af "at have opført sig sømmeligt $~_{8}^{8} \mathrm{Her}$ i Gøtterup fandt hun sig en mand, Hans Alexandersen, som hun blev viet til den 22. februar 1840.9 Han var hufner (boelsmand eller mindre gårdmand). Ham blev hun enke efter den 25 . nov. 1885, hvor han døde i sit 81. år, og hun sad på aftægt efter ham i Gotterup. Berthe Maries far, Nis Sorensen, var første gang gift med Birthe Marie Thomsen, og det er sảledes muligt, at vor Berthe Marie er opkaldt efter sin fars forste kone. Skrinet kan Berthe Marie ikke have arvet efter sin farmoder, som hed Marie Nisdatter, det passer ikke med initialerne K. P. A. D. Der er storre sandsynlighed for, at skrinet stammer fra moderen, Anna Cathrine Andersdatter. Hun blev den 14. dec. 1777 døbt i Nustrup kirke som barn af gårdmand Anders Petersen og Bodil Andersen af Grøngård og fik navnet Cathrine. ${ }^{10}$ K. P. A. D. skal da tydes som Kathrine Peter Anders datter, altså en kombination af hendes og faderens navne. Hun har fået skrinet i 1791 , da hun var ca. 14 år gammel. Om hun har overladt skrinet til datteren Berthe Marie før sin død i marts 1855 , må stâ hen. ${ }^{11}$

Den lille bog rummer foruden titelbladet 11 dobbeltsider, hvoraf der her gengives side 4 (fig. 2), den side, hvor skriften står klarest. Linierne på venstre halvside begynder med en række tal, 7 ialt, 


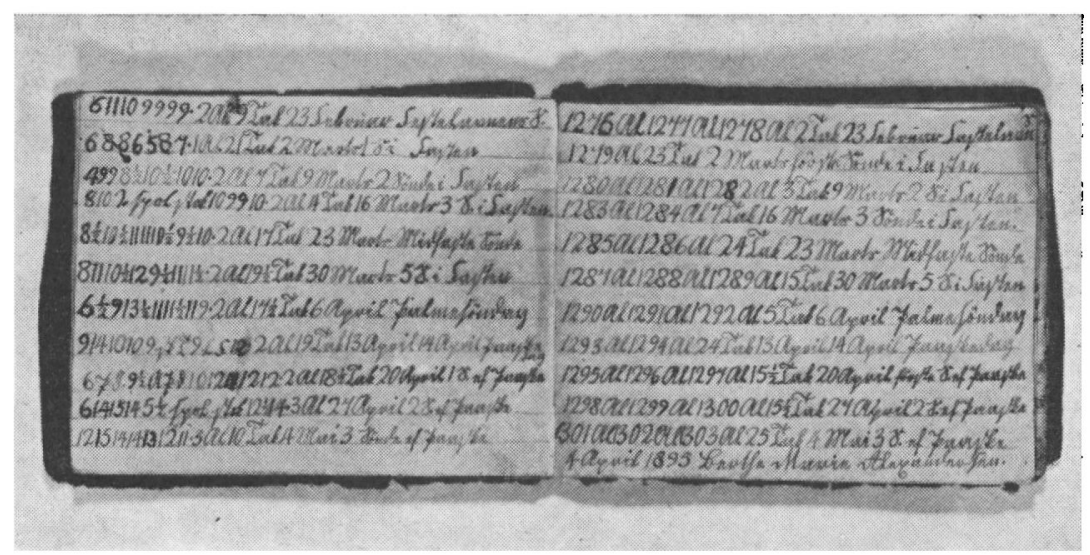

Fig. 2. Ugebogens p. 4.

afsluttet med en prik. De har forst været indfort med blyant og er så senere trukket op med blæk, noget der sikkert er sket søndag morgen, når Berthe Marie gjorde ugens regnskab op, før hun tog fat på den dags kniplearbejde. På den tid var der en vis højtidelighed forbundet med brugen af pen og blæk, og det var passende, at det skete en søndag. Hvert tal dækker en dags udført arbejde $i$ form af takker (i dette tilfælde uden tvivl en hel tunge). Således har Berthe Marie i ugen fra 17. febr. - 23. febr. 1895 om søndagen kniplet 6 takker, næsten fordoblet antallet (til 11) om mandagen, om tirsdagen gået ned til $\mathbf{1 0}$ for derefter at præstere den samme ydelse, 9 takker, resten af ugen. Herpå følger i bogen følgende indførelse: 2 Al. 9 Tak 23. febr. fastelavns s. [søndag]. Disse tal betegner en sammentælling af de foregående tal, omsat til alen efter reglen, at 1 alen er det samme som 27 takker. Omhyggeligt er det angivet, hvilken søndag $\mathrm{i}$ kirkeåret det er. Helligdagene er $\mathrm{i}$ det hele taget ofte markeret $i$ form af forkortelser. Således skrives for eks. skærtorsdag som sk $\mathrm{T}$ og $\mathrm{CH}$ dækker Kristihimmelfartsdag.

Overfor, på sidens højre halvdel, fortsætter de indstregede linier med et antal angivelser $\mathrm{i}$ alen, $\mathrm{i}$ dette tilfælde på side 4 med: 1276 Al 1277 Al 1278 Al samt 2 Tak, som hun har til rest. Hver af disse linier ender igen med datoangivelse, samt hvilken dag det er i kirkeåret. 
På titelbladet anførte Berthe Marie, at hun i den sidste, nu forsvundne ugebog, var náet til 1228 alen 17 takker den 29. september, 19. sondag efter trinitatis. Denne ugebog strækker sig fra den 30. september 1894 til den 8 . februar 1897 , med omhyggelige indførelser for hver dags arbejdsydelse. Gennem 2 ìr og 4 måneder kan man så at sige kigge over skulderen på den gamle kniplerske og følge hendes arbejde, hvis rytme er afstemt efter ugens dage og årstidens skiften fra mørke til lyse dage. Da Berthe Marie fødtes den 18. februar 1819, har hun været $i$ sit 76 . år, da hun begyndte på ugebogen i september 1894, og indforelserne ophorte nogle få dage, for hun fyldte 78 år. I lobet af denne tid har den gamle kvinde kniplet godt og vel $\mathbf{4 0 0}$ alen af den samme knipling. Da ugebogen slutter den 8 . febr. 1897, har hun náet at kniple 1623 alen 12 tak, d.v.s. $1019 \mathrm{~m}$, en imponerende læengde på mere end $1 \mathrm{~km}$. Hun dor 2 år og $5 \mathrm{mdr}$. efter, at ugehogen er afbrudt. Det er ikke godt at vide, om hun overhovedet rorle knipleskrinet efter den 8. febr., man må gå ud fra, at hun er blevet så svagelig og aflægs, at hun hverken kunne indfore $i$ ugebogen eller endsige tage fat på kniplestokkene. Nogle kniplersker har kunnet holde til de halvfems är; de blev ved, til synet svigtede, og til hænderne rystede for meget til at kunne satte nailene $\mathbf{i}$ de fine huller.

Berthe Marie blev som navnt enke den 25. nov. 1885, 11 år fur bogen sluttede. Hvis hun har holdt den samme gennemsnitshastighed hele tiden som den, der kan erkendes gennen de mere end 2 ar, ugebogen spænder over, har hun arbejdet ca. 92/3 âr pá denne ene knipling; hvis hastigheden har været som den, hun har holdt $i$ det forste år, bogen er fort, har hun arbejdet 10 år på den. Der er meget, der taler for, at det er en knipling, hun har sat op kort efter mandens død for som afłægtskone at tjene en smule ekstra til livets ophold, vel også for at fylde det tomrum, som uvilkårligt opstår, når en kvinde, der før har haft hænderne fulde af alskens gøremål, pludselig har al for megen tid til sin rådighed. Hun er da faldet tilbage til sit gamle håndværk, knipleriet, som hun blev oplært i i tiden for sit giftermål. Mand og born tog al hendes tid, og forst da hun blev ene, tog hun slægtens gamle knipleskrin frem. Skrinet har, som tidligere pâvist, sikkert været hendes mors. I dennes tid var der talrige professionelle kniplersker vesten for Haderslev, der forsynede de derboende kniplingskræmmere med 
kniplinger. På Berthe Maries tid var industrien helt uddød på den egn, og kun nogle få kniplingshandlere holdt endnu skansen pai Vesteregnen. Hvem Berthe har afsat sine kniplinger til, og hvor tit hun fik "skåret af ", samt hvor stor hendes fortjeneste var, melder den lille ugebog intet om. Det har heller ikke været muligt at spore hendes navn i listerne over den faste stab af kniplersker, som kniplede for den sidste af Tønderindustriens store kniplingshandlere, Ditlev Hansen, Møgeltønder, som dorle farst i 1900 tallet. Om Berthe Marie har afsat sine kniplinger til Hans Hansen i Ballum, som førte det monster i sin monsterprovebog, foreligger der intet sikkert om. Det kan kun siges, at monstret figurerede deri sammen med andre, der var gangsc i 1885.

Indtegnes Berthe Maries arbejdsydelser pai en kurve, er det interessant at se, at der det forste år $1894-1895$ er en stor sammenhæng mellem produktion og dagens langde, idet den største produktion findes i sommermannederne. Maximal produktion findes i begge år $i$ juli måned, hvor hun een dag nár op pá 18 takker, d.v.s. ca. $42 \mathrm{~cm}$, en beundringsværdig længde, og det til trods for, at hun har måtte "flytte op" 2 gange. Hun har uden tvivl kniplet så længe, der overhovedet var lys nok til at se.

Sammenlignes hendes arbejdsydelse $i$ de to fulde år, regnskabet dækker, er det værd at bemærke, at hendes produktion stiger stærkt $\mathbf{i}$ det andet år, hvilket er så meget desto mere interessant. som det er vinterproduktionen, der tiltager. Dette skyldes muligvis, at hun har erhvervet en bedre lyskilde, måske $i$ form af en petroleumslampe, en belysning som forst vandt indpas i Sønderjylland sidst $\mathrm{i}$ århundredet.

Meget kan aflæses af denne arbejdskurve, f. eks. at hendes produktion det første år er nedsat på søn- og helligdage. På de samme dage $\mathrm{i}$ det andet år er arbejdsydelsen jæunt det samme som på søgnedage. Skyldes det måske, at hun var en flittig kirkegænger det første år, men senere er blevet så aflægs eller dårlig til bens, at kirkegangen har måttet indstilles? Forskelligt synes at tyde på, at det er gået jævnt nedad med helbredet, visse sløjhedsperioder manifesterer sig gennem en faldende produktion samt fejl i regnskabsføringen. Den sidstnæunte vil blive gennemgået ud fra et rent regnemæssigt synspunkt i den følgende artikel. Hendes skrift er på den sidste side rystende; helt patetisk er det nul, hun 
har indført nogle få dage, for bogen afbrydes. Meget mod sin vilje må hun have prentet dette nul, men ærlig var hun, og det skulle med, for hun kniplede hver dag, og regnskabet blev ført med vedholdenhed hver dag, så længe hun kunne.

Spoling angives samvittighedsfuldt gennem 1894 og 1895, men findes kun anført et par gange i 1896 , for til sidst slet ikke at noteres. Det betegnes som "spol stok" lige efter, at dagens antal af kniplede takker er indført på dobbeltsidens venstre regnskabs linie (jfr. fig. 2 linie 4). På tabellen er anført på hvilke dage, der er spolet, og på hvilke ugedage det fandt sted, endvidere dagens udbytte af kniplede takker, samt hvor mange alen der er kniplet mellem hver spoling. Det fremgår heraf, at der har været størst behov for spoling $i$ den lyse tid, hvor arbejdsydelsen $i$ form af takker naturligvis var højest; således spoles der godt og vel en gang om måneden $\mathrm{i}$ demne tid, hvorimod spoling har kunnet indskrænkes til hver anden måned $\mathrm{i}$ de mørkere måneder $\mathrm{i}$ det første

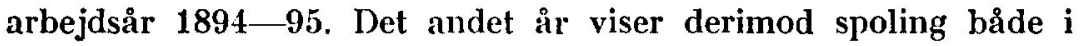
november og december, hvilket hænger sammen med det tidligere anførte forhold, at arbejdsydelsen var steget betydeligt, muligvis på grund af en forbedret lyskilde. Det store alental for eks. mellem 27. juli og 5 . oktober 1895 og 7. december 1895 og 30. maj, tyder på nogle ikke indførte spolinger. En af dem kunne have fundet sted den 1. februar 1896, hvor arbejdsydelsen var meget lille, kun 4 takker. Det udførte arbejde mellem hver spoling ligger mellem 13 og 25 alen.

\section{Spoletabel}

\begin{tabular}{|c|c|c|c|c|c|c|c|}
\hline 1894 & $\begin{array}{r}\text { 6. okt. } \\
\text { 17. nov. }\end{array}$ & $\begin{array}{l}\text { ugens } \\
\text { ugens }\end{array}$ & $\begin{array}{l}\text { 2. dag } \\
\text { 5. dag }\end{array}$ & $\div$ & $\begin{array}{l}\text { takker } \\
\text { takker }\end{array}$ & kniplet & 25 alen \\
\hline 1895 & $\begin{array}{l}\text { 19. jan. } \\
\text { 16. marts } \\
\text { 27. april } \\
\text { 25. maj } \\
\text { 29. juni } \\
\text { 27. juli } \\
\text { 5. okt. } \\
\text { 9. nov. } \\
\text { 7. dec. }\end{array}$ & $\begin{array}{l}\text { ugens } \\
\text { ugens } \\
\text { ugens } \\
\text { ugens } \\
\text { ugens } \\
\text { ugens } \\
\text { ugens } \\
\text { ugens } \\
\text { ugens }\end{array}$ & $\begin{array}{l}\text { 6. dag } \\
\text { 3. dag } \\
\text { 5. dag } \\
\text { 7. dag } \\
\text { 5. dag } \\
\text { 4. dag } \\
\text { 5. dag } \\
\text { 2. dag } \\
\text { 3. dag }\end{array}$ & $\begin{array}{c}3^{1 / 2} \\
2 \\
5^{1 / 2} \\
8 \\
13^{1 / 2} \\
7^{1 / 2} \\
10 \\
8 \\
8\end{array}$ & $\begin{array}{c}\text { takker } \\
\text { takker } \\
\text { takker } \\
\text { takker } \\
\text { takker } \\
\text { takker } \\
\text { takker } \\
\text { takker } \\
\text { takker }\end{array}$ & $\begin{array}{l}\text { kniplet } \\
\text { kniplet } \\
\text { kniplet } \\
\text { kniplet } \\
\text { kniplet } \\
\text { kniplet } \\
\text { kniplet } \\
\text { kniplet } \\
\text { kniplet }\end{array}$ & $\begin{array}{l}20 \text { alen } \\
18 \text { alen } \\
15 \text { alen } \\
13 \text { alen } \\
19 \text { alen } \\
17 \text { alen } \\
42 \text { alen } \\
17 \text { alen } \\
13 \text { alen }\end{array}$ \\
\hline 1896 & $\begin{array}{l}\text { 1. febr. } \\
\text { 30. maj } \\
\text { 8. aug. }\end{array}$ & $\begin{array}{l}\text { ugens } \\
\text { ugens } \\
\text { ugens }\end{array}$ & $\begin{array}{l}\text { 4. dag } \\
\text { 7. dag } \\
\text { 5. dag }\end{array}$ & $\begin{array}{r}4 \\
8 \\
11\end{array}$ & $\begin{array}{l}\text { takker } \\
\text { takker } \\
\text { takker }\end{array}$ & $\begin{array}{l}\text { (spoling } \\
\text { kniplet } \\
\text { kniplet }\end{array}$ & $\begin{array}{l}\text { ikke anf } ø r t) \\
80 \text { alen } \\
39 \text { alen }\end{array}$ \\
\hline
\end{tabular}


Af ugens talnummer fremgår det, at Berthe Marie aldrig spolede på ugens 1 . dag, om søndagen, endvidere at der kun undtagelsesvis har fundet spoling sted på ugens 7. dag, om lørdagen (den 25. maj 1895 og den 30. maj 1896). Kniplet har hun derimod om søndagen, og selvom arbejdsudbyttet i alle fald i 1894 og 1895 er betydeligt lavere på disse, såvel som de ovrige helligdage som jule-, nytårs-, påske- og pinsedagene, så er det en regel, at knipleskrinet var $\mathrm{i}$ brug om søndagen, et træk der ikke stemmer overens med de oplysninger, der er fremkommet ved udspørgning af gamle kniplersker og deres efterkommere i Tønderegnen, hvor det fastholdes, at man ikke kniplede om søndagen, der helligedes kirkegang. Derimod var spoling af kniplestokke $i$ hånden tilladt. Vi står her over for to modstridende overleveringer, som muligvis kan forklares på den måde, at Berthe Maries arbejdsmetode betegner et ældre lag $\mathrm{i}$ traditionen. Hun kan have anvendt speltning, en metode der her $\mathrm{i}$ landet hidtil kun er påvist at være anvendt af vævere. ${ }^{12}$ Ved speltning anvendes en speltepind, en tilspidset pind, der bliver sat fast ind i rokkens nåleøje. Her bliver islætten vundet op på væveskyttelen, almindeligvis et ledstykke af tagrør, der stikkes ind over speltepinden. Ifølge Feilberg ${ }^{13}$ er ordet speltepind vestslesvigsk.

Et lille redskab, hvis anvendelse var ret dunkel, fandtes $i$ et knipleskrin på Haderslev Amts Museum; ${ }^{14}$ det stammer fra en professionel kniplerske Karen Tweed, datter af skomager Tweed i Kastrup. Hun er født 1828 og døde 1907. Redskabet er tragtformet og måler $0,067 \mathrm{~m}$ med en diameter på $0,022 \mathrm{~m}$ over tragtens hul. Forneden er det forsynet med en lille pindformet tap. Stykket er skåret ud af eet stykke træ og dekoreret med en lille sløjfe samt bogstavet $\mathrm{T}$. At det var knyttet til en kniplerskes arbejde på en eller anden måde var indlysende, men dets egentlige brug blev forst klargjort gennem en tegning af speltning af kniplestokke, således som det foregik blandt finske kniplersker, der anvendte et identisk redskab, når de spolede kniplestokke på rokken. ${ }^{15}$ Fremgangsmåden er ydermere blevet forklaret af en kniplerske $i$ Møgeltønder, der har flere generationer af professionelle kniplersker bag sig. Speltepindens spidse ende blev stukket ind i rokkens trådøje, i den tragtformede del holdtes kniplestokken på plads ved presset af fingeren. For at beskytte den finger, om hvilken 


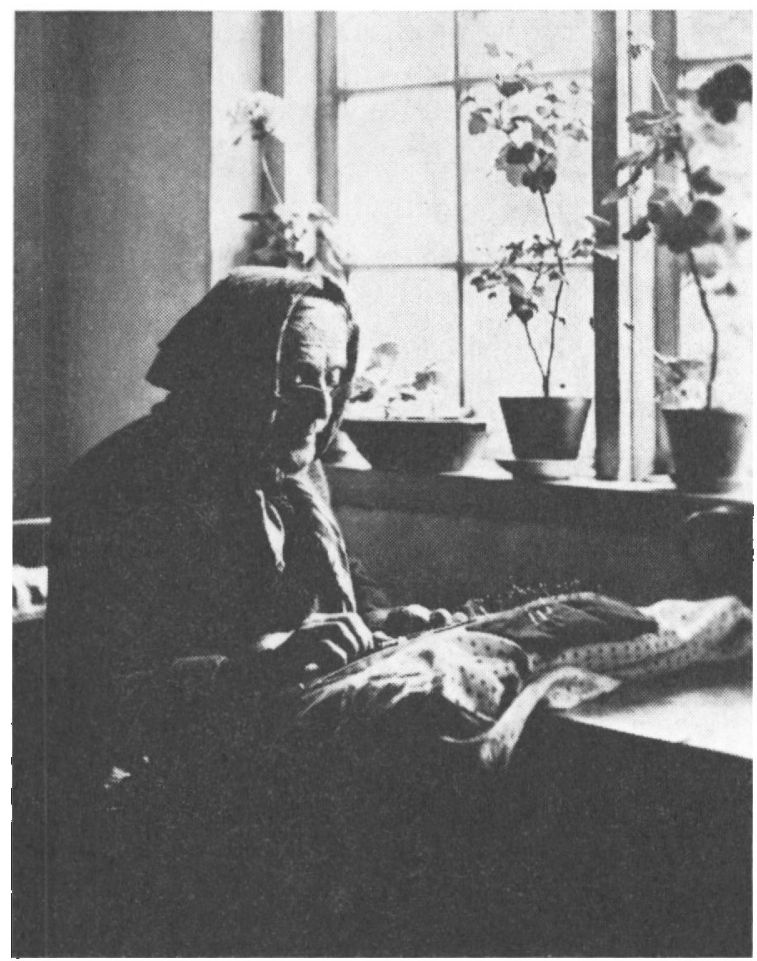

Fig. 3. Gammel kniplerske (fot. 1912 af afd. godsinspekter Datidisen, Mageltander).

trâden lob under spolingen, anvendtes me slawbrev", et stykke papir.

Har Berthe Marie anvendt speltning, når hun skulle spole sine kniplestokke, har hun vel også haft en grund til ikke at gøre dette stykke arbejde om sondagen.

Megen overtro er knyttet til rokken. ${ }^{16}$ De gamle koner tog altid snoren af rokkehjulet lørdag aften til mandag morgen af angst for, at de underjordiske eller heksene skulle spinde om natten. Spinding om søndagen ansås for ganske forkasteligt. Det var et arbejde, der aldrig udførtes denne dag, fordi det var mere utilladeligt end alt andet arbejde. Forbudet gjaldt også lordag aften, da helligdagene $i$ hine tider regnedes for at begynde aftenen før. Der findes en række "vandresagn " om genfærd, der har forbrudt sig mod dette forbud, thi som det hedder i Skattegraveren, ${ }^{17}$ »den 
der spinder om sondagen skal spinde efter sin dod". Sảledes stàr en spinderske med rodglodende hånd foran sin rok og jamrer » Ha ka I sie hur a haa van / faa de a on Lowerda Awd'enen spand. En anden viser sig uden for vinduet i sit hjem, helt rodglodende, og udstoder den samme klage.

At Berthe Marie har spolet et par lordage kan godt forenes med forbudel om at bruge rokken, idet der intet er $i$ vejen for, at hum mâtle spole tidligt på denne dag. Som tidligere anfort var stokkene pai Berthe Maries skrin af en gammeldags type med glatte agformede doppe, en form der var velegnet til at stikke ind i tragten pâ speltepinden. De starkt profilerede perleprydede doppe pä de langt spinklere kniplestokke, som anvendtes gennem 1800 tallet af Tonderegnens kniplersker, egner sig derimod darlint dertil. Det er muligt, at vi her har forklaringen på, at kniplerskerne da mátte spole stokkene $\mathrm{i}$ handen, et arbejde, der ikke nodvendiggjorde brugen af rokken, og som derfor udmærket kunne fylde ledige stunder på son- og helligdage.

Dette er, hvad den lille ugebog fortaller om Berthe Maries arbejde gennem mere end 2 år. Men hvad rober den og knipleskrinet on hende selv? Skrinets slidte tilstand og det lidet pyntelige udstyr synes at antyde, at hun har hort til de sparsommelige, som kviede sig ved udgifter udover det strengt nodvendige. Om hun har været tvunget hertil af okonomiske grunde er svart at sige. Hun kommer fra en gårdmandsfamilie og bliver gift ind $\mathrm{i}$ samme miljø og hører sâledes ikke til den laveste del af almuen som kådnere og inderster, hvorfra storstedelen af kniplerskerne rekrutteredes pa l'esteregnen.

Kniplingens fine kvalitet, til trods for det starkl slidte prikbrev, viser, at Berthe Marie var en dygtig og habil kniplerske, der mestrede sin kunst til fulde. At hun tilmed var glad for sit arbejde, antydes af den flid og vedholdenhed, hun har lagt for dagen gennem de mere end 2 år, det har været muligt at folge hendes arbejde gennem ugebogens indfarelser, som er udført med en påpasselighed og sirlighed, der næsten grænser til det sippede, altsammen egenskaber der kun var en kniplerske til gode. Til trods for sin høje alder har hun udvist en udholdenhed og sejghed, som også var karakteristisk for mange af de gamle, professionelle kniplersker fra Vesteregnen, som f. eks. den på fig. 3 afbildede knip- 
lerske fra Møgeltønder, der kniplede indtil et par dage, før hun døde i den høje alder af 83; hun levede nogenlunde samtidig med Berthe Marie. ${ }^{18}$

Af ugebogens sidste indførsel fremgik det, at Berthe Marie nåede at kniple ca. $1 \mathrm{~km}$ af den samme knipling, som hun har siddet med i mange år på skrinet, et fænomen, som kendes fra beretninger om kniplersker på Vesteregnen, hvor N. C. Rom ${ }^{19}$ beretter om en gammel kone, der igennem 40 år havde kniplet det samme, smalle monster. Med skrinet fra Gotterup fulgte der som nevint 12 prikbreve, som enten kunne stamme fra Berthe Marie eller hendes moder. Hun kan således godt have kniplet efter disse, men har de sidste år af sin levetid slået sig til tåls med et enkelt monster, som hun har fundet tilfredsstillende at udføre år efter år. Hun kan have følt en vis glæde og spænding ved de små indførelser hver dag i ugebogen, og tallene kan have ansporet hende til en jævn arbejdsydelse, og de har således på en måde hjulpet hende til at "holde fanen højt " til trods for alderdommens tiltagende besværligheder. Den lille ugebog står derfor som et minde om en gammel kvindes tapperhed og udholdenhed. 


\section{NOTER og HENVISNINGER}

1. Haderslev Amts Museum nr. 613. Til skrinet horte desuden 12 prikbreve af pergament, som desværre nu er bortkommet. Museet overlod velvilligst skrin og ugebog til fotografering på Nationalmuseet ved Lennart Larsen.

2. Schleswig Holsteinisches Landesmuseum, Gottorp Slot, O.B. 2435. Proveniens: Nordschleswig.

3. Lin fra Søsum, Stenlose sogn. Nationalmuscet III 32/1932.

4. Flensburg Museum $7576^{2}$ p. 13 no. 1 . Dirligere udfort udgave findes ibidem p. 54.

5. Tislund kirkebog under dode og begravede 1899 .

6. Osterlinnet kirkebog: fodte Kvindekon 1819.

7. Tislund kirkelog. Tilgangsliste no. 117-118.

8. ibidem: confirmerede Piger 1835.

9. ibidem: Copulerede 1840.

10. Nustrup kirkebog: Døbte 1777.

11. Tislund kirkebog: Dode kvindekøn 1855.

12. H. F. Feilberg: Dansk Bondeliv I, 1922 p. 70 og 125. Ole Hojrup: Landbokvinden, rok og kærne etc. 1964 p. 241.

13. H. F. Feilberg: Ordbog over jyske Almuemál III, p. 482-83.

14. Haderslev Amts Museum nr. 5347.

15. Aino Linnove: Suomalaisen pitsinnypläyksen kehitysvaiheita 1500luvulta 1850-luvulle. Porvoo. Helsinki 1947 p. $156 \mathrm{fig} .77$ viser en tegning af speltning, p. 314 fig. 268 et foto af to kvinder, hvoraf den ene knipler, den anden spelter pă en rok.

16. Danmarks Folkeminders kartotek under stikordet "Rundt", "H.jul", »Sondage".

17. Skattegraveren VII p. 512.

18. Billedet er taget 1912 af afd. godsinspektor H. C. Davidsen, Mogeltønder. Kniplersken hed Anne Friis, men kaldtes Anne Just. Hun var fodt $1829 \mathrm{og}$ døde 1912 . Eldre billede af samme findes $i$ Sprogforeningens Almanak 1909.

19. N. C. Rom: Danske Husflid, 1862 p. 392. 